\title{
Primary Malignant Mesothelioma of the Liver: Case Report and Review of the Literature
}

\author{
Subash Ghimire $^{1}$, Nilisha Regmi ${ }^{2}$, Tsujung Yang ${ }^{1}$, Harshil Shah $^{1}$, Ukorn Srivatana ${ }^{1}$, Ashit Sarker ${ }^{1}$, Hafiz Khan ${ }^{1}$ \\ ${ }^{1}$ Guthrie Robert Packer Hospital, Sayre, PA, USA \\ ${ }^{2}$ Jinnah Sindh Medical College, Karachi, Pakistan
}

Received: 04/11/2020

Accepted: $10 / 11 / 2020$

Published: $18 / 12 / 2020$

\begin{abstract}
How to cite this article: Ghimire S, Regmi N, Yang T, Shah H, Srivatana U, Sarker A, Khan H. Primary malignant mesothelioma of the liver: case report and review of the literature. EJCRIM 2020;7: doi:10.12890/2020_002128.
\end{abstract}

Conflicts of Interests: The Authors declare that there are no competing interests.

This article is licensed under a Commons Attribution Non-Commercial 4.0 License

\section{ABSTRACT}

Introduction: Primary malignant mesothelioma of the liver is an extremely rare cancer, with only 16 cases reported in the literature so far. Diagnosis is challenging due to morphological similarity with common liver cancers and the extreme rarity of the condition.

Case description: We present the case of a 70-year-old man who was found to have an incidental liver mass which was diagnosed as primary malignant mesothelioma of the liver.

Conclusion: Our report describes the presentation of this rare liver malignancy and the challenges associated with diagnosis and treatment.

\section{LEARNING POINTS}

- Primary malignant mesothelioma of the liver is an extremely rare condition.

- This diagnosis should be considered during the evaluation and treatment of a liver mass.

\section{KEYWORDS}

Primary malignant mesothelioma, liver cancer, asbestosis

\section{INTRODUCTION}

Primary malignant mesothelioma of the liver is an extremely rare tumour with only 16 previously reported cases. Although asbestos exposure has been linked to $80 \%$ of cases of pleural mesothelioma and to $33-50 \%$ of cases of peritoneal mesothelioma, an association between asbestos exposure and hepatic mesothelioma has not yet been established. Hepatic mesothelioma is not currently listed in the WHO classification of hepatic tumours ${ }^{[1]}$.

We present a case of primary intrahepatic mesothelioma in a 70-year-old man with asbestos exposure and provide a literature review of the cases reported to date.

\section{CASE DESCRIPTION}

A 70-year-old male patient was being followed up at our hospital for pulmonary asbestosis with an annual low-dose CT scan, when an incidental liver mass was detected. His previous CT scan had shown evidence of a stable calcified pleural plaque with no pleural or hepatic lesions. He was completely asymptomatic and showed no signs of jaundice or right upper quadrant tenderness ${ }^{[2]}$.

A CT scan of the abdomen with contrast was obtained and showed a well-defined $8 \mathrm{~cm}$ mass with heterogenous enhancement involving the right lobe of the liver, predominantly segment VI (Fig. 1). The hepatic vein and portal vein were patent. Since the mass was highly suggestive of malignancy, a detailed work-up was planned. A chest CT scan did not show any evidence of haematogenous metastasis or 
pleural involvement. Laboratory findings showed liver function tests and alfa fetoprotein (AFP) within normal ranges. The viral markers for hepatitis $B$ and hepatitis $C$ were negative.

The patient underwent surgical resection with partial hepatectomy (segments V/VI) and cholecystectomy; part of the diaphragm was also resected. Biopsy of the liver mass showed poorly differentiated malignancy with areas of epithelioid and spindle cell differentiation (Fig. 2). Immunohistochemically, tumour cells were positive for keratin AE1/AE3, keratin CAM 5.2, WT1, calretinin, CK20 and D2-40, but negative for CD34, arginase, CK5/6, CK7, ERG, mucicarmine, MOC 31, BerEp4, desmin, S-100, and albumin in situ hybridization. The overall morphology as well as immunohistochemical staining were most consistent with poorly differentiated malignant mesothelioma.

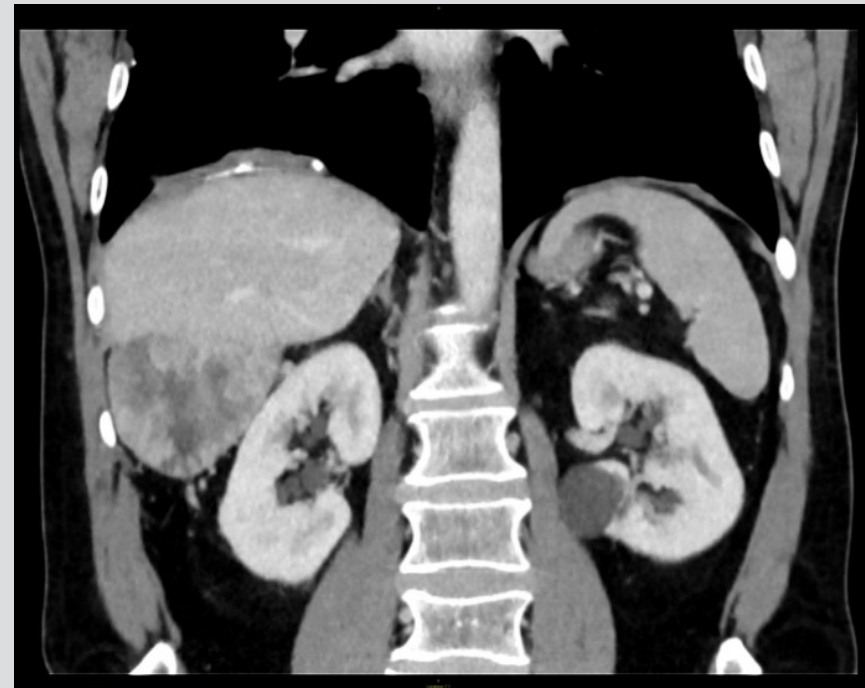

Figure 1. CT scan showing an $8 \mathrm{~cm}$ mass in the liver

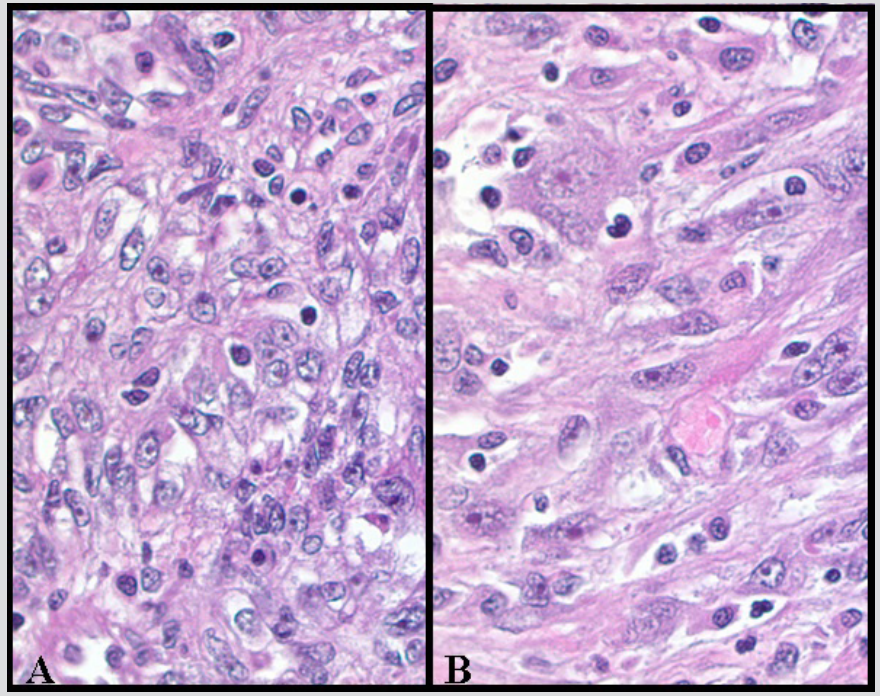

Figure 2. Tumour cells showing epithelioid (A) and spindle cell

(B) differentiation (H\&E stain, $\times 400)$

After surgery, the patient was started on four cycles of pemetrexed and cisplatin as adjuvant therapy, while being monitored for signs of relapse or distant metastasis. So far, there has been no evidence of any new lesions or metastasis, 15 months after surgery.

\section{DISCUSSION}

Primary intrahepatic mesothelioma (PIHMM) is an extremely rare tumour with only 16 cases reported in the literature to date ${ }^{[3]}$. Mesothelial cells form a layer covering Glisson's capsule but are not present in the liver parenchyma physiologically. Although evidence concerning the origin of liver mesothelioma is unclear, considering the subcapsular location in the majority of cases, many authors have speculated that it originates from Glisson's capsule and eventually invades the liver ${ }^{[4]}$.

A review of the literature (Table 1) revealed that age at diagnosis ranged from 36 to 70 years (mean: 58 years). Of the diagnosed cases, $62.5 \%$ were male and $37.5 \%$ were female, showing a slight male preponderance. One case described by Imura et al. was associated with cirrhosis due to hepatitis $\mathrm{C}$ infection ${ }^{[5]}$. Another patient diagnosed with biphasic type mesothelioma had a history of asbestos exposure, making our case the second in the literature to be associated with asbestos exposure. Although there is an association between asbestos and pleural and peritoneal mesothelioma, the association with hepatic mesothelioma is still unclear ${ }^{[6]}$.

Clinically, the majority of patients present with non-specific symptoms such as abdominal pain, weight loss and low-grade fever. In $25 \%$ (4/16) of cases, and in our patient, PIHMM was detected as an incidental finding of a localized subcapsular nodular lesion in the right lobe. The average diameter of the tumour was $11 \mathrm{~cm}(3.2-21 \mathrm{~cm})$. CT scanning with contrast was the imaging modality of choice in all cases. In the majority of cases, it presented as a well-circumscribed tumour with abnormal heterogenous enhancement and areas of necrosis and haemorrhage. Post-contrast enhancement of peripheral serpiginous vascular structure and septal enhancement was also noted.

Histologically, malignant mesothelioma can be divided into three different types: epithelioid, sarcomatoid and biphasic (a mixture of epithelioid and sarcomatoid). Epithelioid is the most common type and can be tubulopapillary or solid and surrounded by either desmoplastic stroma or mixed inflammatory infiltrates. 


\begin{tabular}{|c|c|c|c|c|c|c|c|c|c|}
\hline & Year & $\begin{array}{l}\text { Age } \\
\text { (years) }\end{array}$ & Sex & $\begin{array}{l}\text { Size } \\
(\mathrm{cm})\end{array}$ & $\begin{array}{l}\text { Asbestos } \\
\text { exposure }\end{array}$ & $\begin{array}{l}\text { Lobe } \\
\text { involved }\end{array}$ & Histology & Symptoms & Outcome \\
\hline Imura et al.(5) & 2002 & 64 & $M$ & 3.2 & No & Right & Epithelioid & Incidental finding & $\begin{array}{l}\text { No recurrence } 40 \text { months after } \\
\text { surgery }\end{array}$ \\
\hline $\begin{array}{l}\text { Leonardou et al. } \\
\text { (10) }\end{array}$ & 2003 & 54 & $M$ & 16 & N/A & Right & Epithelioid & Abdominal pain & $\begin{array}{l}\text { No recurrence } 60 \text { days after } \\
\text { surgery }\end{array}$ \\
\hline Di Blasi et al.(11) & 2004 & 61 & $M$ & 10 & $N / E$ & Right & Epithelioid & $\begin{array}{l}\text { Weakness and mild } \\
\text { abdominal pain }\end{array}$ & $\begin{array}{l}\text { Metastasis in inguinal } \\
\text { lymph nodes and pelvic } \\
\text { peritoneum } 3 \text { years after } \\
\text { surgery }\end{array}$ \\
\hline Gütgemann et al. (8) & 2006 & 62 & $M$ & 5.8 & No & Right & Epithelioid & $\begin{array}{l}\text { Non-specific upper } \\
\text { abdominal discomfort }\end{array}$ & $\begin{array}{l}\text { Metastasis to periaortic and } \\
\text { thoracic lymph nodes 5, } \\
12 \text { and } 20 \text { months after } \\
\text { surgery }\end{array}$ \\
\hline Kim et al.(12) & 2008 & 53 & $M$ & 13 & No & Right & Epithelioid & Incidental finding & $\begin{array}{l}\text { Local recurrence and diaphragm } \\
\text { invasion } 15 \text { and } 23 \text { months } \\
\text { after surgery }\end{array}$ \\
\hline Sasaki et al.(6) & 2009 & 66 & $M$ & 4 & Yes & Right & Biphasic & $\begin{array}{l}R \cup Q \text { pain with weight } \\
\text { loss }\end{array}$ & $\begin{array}{l}\text { No recurrence at 6-month } \\
\text { follow-up }\end{array}$ \\
\hline Inagaki et al.(13) & 2013 & 68 & $F$ & 7 & No & Right & Epithelioid & $\begin{array}{l}\text { Prolonged low-grade } \\
\text { fever }\end{array}$ & $\begin{array}{l}\text { Rapid growth of tumour } \\
\text { complicated by hepatic } \\
\text { rupture, 3-month survival }\end{array}$ \\
\hline Dong et al.(14) & 2014 & 50 & $F$ & Multiple & No & Bilateral & Epithelioid & RUQ pain & $N / A$ \\
\hline Perysinakis et al. (15) & 2014 & 66 & $M$ & 17 & No & Right & Epithelioid & $\begin{array}{l}\text { Weakness, incidental } \\
\text { finding }\end{array}$ & $\begin{array}{l}\text { No recurrence } 36 \text { months after } \\
\text { surgery }\end{array}$ \\
\hline Serter et al.(16) & 2014 & 56 & $F$ & 15 & No & Right & Epithelioid & $\begin{array}{l}\text { Abdominal pain and } \\
\text { weakness }\end{array}$ & $\begin{array}{cr}\text { Intraoperative } & \text { peritonitis, } \\
\text { carcinomatosis } & \text { with } \\
\text { omental cake } & \end{array}$ \\
\hline Serter et al.(16) & 2014 & 66 & $M$ & 14 & No & $\begin{array}{l}\text { Left } \\
\text { (lateral } \\
\text { segment) }\end{array}$ & Biphasic & $\begin{array}{l}\text { Abdominal pain and } \\
\text { weight loss }\end{array}$ & $\begin{array}{l}\text { Direct invasion to stomach and } \\
\text { tail of pancreas }\end{array}$ \\
\hline Ali et al.(9) & 2016 & 41 & $F$ & 21 & No & Right & Biphasic & $\begin{array}{l}\text { RUQ pain, weight loss, } \\
\text { low-gradefever }\end{array}$ & $N / A$ \\
\hline Minami et al.(17) & 2017 & 36 & $F$ & 13 & No & Right & Epithelioid & Abdominal and back pain & $\begin{array}{l}\text { Intraoperative direct omental } \\
\text { invasion. No recurrence at } \\
6 \text { months }\end{array}$ \\
\hline Ismael et al.(4) & 2018 & 60 & $M$ & 11.3 & No & Right & Epithelioid & RUQ pain, weight loss & $N / A$ \\
\hline Wong et al.(18) & 2019 & 55 & $F$ & 18 & No & Right & Epithelioid & $\begin{array}{l}\text { Non-specific abdominal } \\
\text { pain }\end{array}$ & $\begin{array}{l}\text { No recurrence } 8 \text { years after } \\
\text { surgery }\end{array}$ \\
\hline Present case & 2019 & 70 & $M$ & 8 & Yes & Right & Epithelioid & Incidental finding & $\begin{array}{l}\text { No recurrence } 15 \text { months after } \\
\text { surgery }\end{array}$ \\
\hline
\end{tabular}

The clinician should keep in mind other primary and secondary tumours such as hepatocellular carcinoma, cholangiocarcinoma and a metastasized adenocarcinoma when investigating malignant mesothelioma of the liver. Immunohistochemistry helps in the definitive diagnosis of the tumour. A mesothelial origin was proven by positive calretinin, WT-1, cytoplasmic D2-40, cytokeratins, CK AE1/AE3, thrombomodulin staining and negative CD34, Ber-EP4, MOC-31, CEA, AFP and CA-19-9[1,3]. Calretinin, a 29-kDa protein that belongs to a family of calcium-binding proteins, is highly sensitive and specific in diagnosing epithelioid mesothelioma ${ }^{[7,8]}$. 
Treatment is with surgical removal of the tumour and the attached portion of the. Some $37.5 \%(6 / 16)$ of cases reported in the literature showed invasion beyond their original site, metastasis or local recurrence, while $37.5 \%(6 / 16)$ of cases had no recurrence after surgery ${ }^{[4,9]}$.

\section{CONCLUSION}

Primary malignant mesotheliomas are rare tumours detected as well-circumscribed, subcapsular lesions particularly in the right lobe of the liver. Due to the limited number of described cases, the association between asbestos exposure and hepatic mesothelioma is still unclear. Hence, more cases should be reported, while asbestos exposure is kept in mind, to provide a clear understanding. This diagnosis should be considered in the evaluation of liver mass.

\section{REFERENCES}

1. Sekido Y. Molecular pathogenesis of malignant mesothelioma. Carcinogenesis. 2013:34(7):1413-9.

2. Ghimire S, Yang T, Shah H, Srivatana U, Sarker A. primary malignant mesothelioma of liver: a rare liver tumor. Am J Gastroenterol 2019;114(1):S1257-S1257.

3. Kim J, Bhagwandin S, Labow DM. Malignant peritoneal mesothelioma: a review. Ann Transl Med 2017;5(11):236. doi: 10.21037/atm.2017.03.96.

4. Ismael H, Cox S. Primary intrahepatic mesotheliomas: A case presentation and literature review. Int J Surg Case Rep 2018;47:1-6.

5. Imura J, Ichikawa K, Takeda J, Iwasaki Y, Tomita S, Kubota K, et al. Localized malignant mesothelioma of the epithelial type occurring as a primary hepatic neoplasm: A case report with review of the literature. APMIS 2002;110(11):789-94.

6. Sasaki M, Araki I, Yasui T, Kinoshita M, Itatsu K, Nojima T, et al. Primary localized malignant biphasic mesothelioma of the liver in a patient with asbestosis. World J Gastroenterol 2009;15(5):615-21.

7. Kim H, Damjanov I. Localized fibrous mesothelioma of the liver. Report of a giant tumor studied by light and electron microscopy. Cancer 1983;52(9):1662-5.

8. Gütgemann I, Standop J, Fischer HP. Primary intrahepatic malignant mesothelioma of epithelioid type. Virchows Arch 2006;448(5):655-8.

9. Haji Ali R, Khalife M, EI Nounou G, Zuhri Yafi R, Nassar H, Aidibe Z, et al. Giant primary malignant mesothelioma of the liver: A case report. Int J Surg Case Rep 2017;30:58-61.

10. Leonardou P, Semelka RC, Kanematsu M, Braga L, Woosley JT. Primary malignant mesothelioma of the liver: MR imaging findings. Magn Reson Imaging 2003;21(9):1091-3.

11. Di Blasi A, Boscaino A, De Dominicis G, Marsilia GM, D’Antonio A, Nappi O. Multicystic mesothelioma of the liver with secondary involvement of peritoneum and inguinal region. Int J Surg Pathol 2004;12(1):87-91.

12. Kim DS, Lee SG, Jun SY, Kyoung WK, Ha TY, Kim KK. Primary malignant mesothelioma developed in liver. Hepatogastroenterology 2008; 55:1081-1084

13. Inagaki N, Kibata K, Tamaki T, Shimizu T, Nomura S. Primary intrahepatic malignant mesothelioma with multiple lymphadenopathies due to non-tuberculous mycobacteria: A case report and review of the literature. Oncol Lett 2013; 6(3):676-80.

14. Dong A, Dong H, Zuo C. Multiple primary hepatic malignant mesotheliomas mimicking cystadenocarcinomas on enhanced CT and FDG PET/CT. Clin Nucl Med 2014;39(7):61922.

15. Perysinakis I, Nixon AM, Spyridakis I, Kakiopoulos G, Zorzos C, Margaris I. Primary intrahepatic malignant epithelioid mesothelioma. Int J Surg Case Rep 2014:5(12):1098-101.

16. Serter A, Buyukpinarbasili N, Karatepe O, Kocakoc E. An unusual liver mass: primary malignant mesothelioma of the liver: CT and MRI findings and literature review. Jpn J Radiol 2014;33(2):102-6.

17. Minami K, Okumura H, Hiwatashi K, Matsukita S, Setoyama T, Minamimagari K, et al. Multiple malignant epithelioid mesotheliomas of the liver and greater omentum: a case report and review of the literature. Surg Case Reports 2017;3(1).

18. Wong S, Gargi D, Cha C, Klimstra D, Jain D. Primary mesothelioma of the iver: a case report. Ajsp Rev Reports 2019;24(4). 